\title{
GENERAL CONSIDERATION ON JAPANESE APPENDICULARIAN FAUNA
}

$\operatorname{AUTHOR(S):~}$

Tokioka, Takasi

\section{CITATION:}

Tokioka, Takasi. GENERAL CONSIDERATION ON JAPANESE

APPENDICULARIAN FAUNA. PUBLICATIONS OF THE SETO MARINE BIOLOGICAL LABORATORY 1955, 4(2-3): 251-261

\section{ISSUE DATE:}

1955-05-30

URL:

http://hdl.handle.net/2433/174523

RIGHT: 


\title{
GENERAL CONSIDERATION ON JAPANESE APPENDICULARIAN FAUNA ${ }^{13}$
}

\author{
TAKASI TOKIOKA
}

Seto Marine Biological Laboratory, Sirahama

With 6 Text-figures

\section{Species Occurring in Japanese Waters and the Neighbouring Seas.}

So far as I am aware, the following 34 species of appendicularians are found in reports dealing with this animal group occurring in Japanese waters and the neighbouring seas.

Oikopleuridae

Oikopleura (Coecaria) longicauda VogT $\left(\mathrm{A}, \mathrm{T}_{1}, \mathrm{~T}_{2}, \mathrm{~T}_{3}\right.$ )

Oikopleura (Coecaria) fusiformis FoL $\left(\mathrm{A}, \mathrm{T}_{1}, \mathrm{~T}_{2}, \mathrm{~T}_{3}\right.$ )

Oikopleura (Coecaria) intermedia LoHMANN (=Oik. microstoma AIDA)

$\left(\mathrm{A}, \mathrm{T}_{1}, \mathrm{~T}_{2}\right.$ )

*Oikopleura (Coecaria) cornutogastra AIDA $\left(\mathrm{A}, \mathrm{T}_{2}, \mathrm{~T}_{3}\right.$ )

Oikopleura (Coecaria) graciloides LoHMANN \& BückmanN $\left(\mathrm{T}_{2}\right)$

Oikopleura (Coecaria) gracilis LoHMANN $\left(\mathrm{T}_{3}\right)$

Oikopleura (Vexillaria) dioica FoL $\left(\mathrm{A}, \mathrm{T}_{1}, \mathrm{~T}_{2}, \mathrm{~T}_{3}\right.$ )

Oikopleura (Vexillaria) rufescens FoL $\left(\mathrm{A}, \mathrm{T}_{1}, \mathrm{~T}_{2}, \mathrm{~T}_{3}\right)$

Oikopleura (Vexillaria) parva LOHMANN $\left(\mathrm{T}_{3}\right)$

Oikopleura (Vexillaria) cophocerca GegEnBauR $\left(\mathrm{T}_{1}, \mathrm{~T}_{2}, \mathrm{~T}_{3}\right.$ )

Oikopleura (Vexillaria) albicans (LEUCKART) $\left(\mathrm{T}_{1}\right)$

Oikopleura (Vexillaria) labradoriensis LoHmann $\left(\mathrm{T}_{1}, \mathrm{~T}_{3}\right)$

*Oikopleura (Vexillaria) chamissonis Mertens (Mertens 1831)

Megalocercus huxleyi (RITTER) (=Oik. megastoma AIDA) ( $\mathrm{A}, \mathrm{T}_{1}, \mathrm{~T}_{2}, \mathrm{~T}_{3}$ )

Stegosoma magnum (LANGERHANS) (A, $\mathrm{T}_{1}, \mathrm{~T}_{2}, \mathrm{~T}_{3}$ )

* Chunopleura microgaster LOHMANN $\left(\mathrm{T}_{1}\right)$

Pelagopleura verticalis (LOHMANN) $\left(\mathrm{T}_{2}\right)$

*Pelagopleura sp. $\left(\mathrm{T}_{1}, \mathrm{~T}_{3}\right)$

Fritillaridae

Fritillaria (Acrocercus) haplostoma FoL $\left(\mathrm{A}, \mathrm{T}_{1}, \mathrm{~T}_{2}, \mathrm{~T}_{3}\right)$

1) Contributions from the Seto Marine Biological Laboratory, No. 258.

Publ. Seto Mar. Biol. Lab., IV (2-3), 1955. (Article 21) 


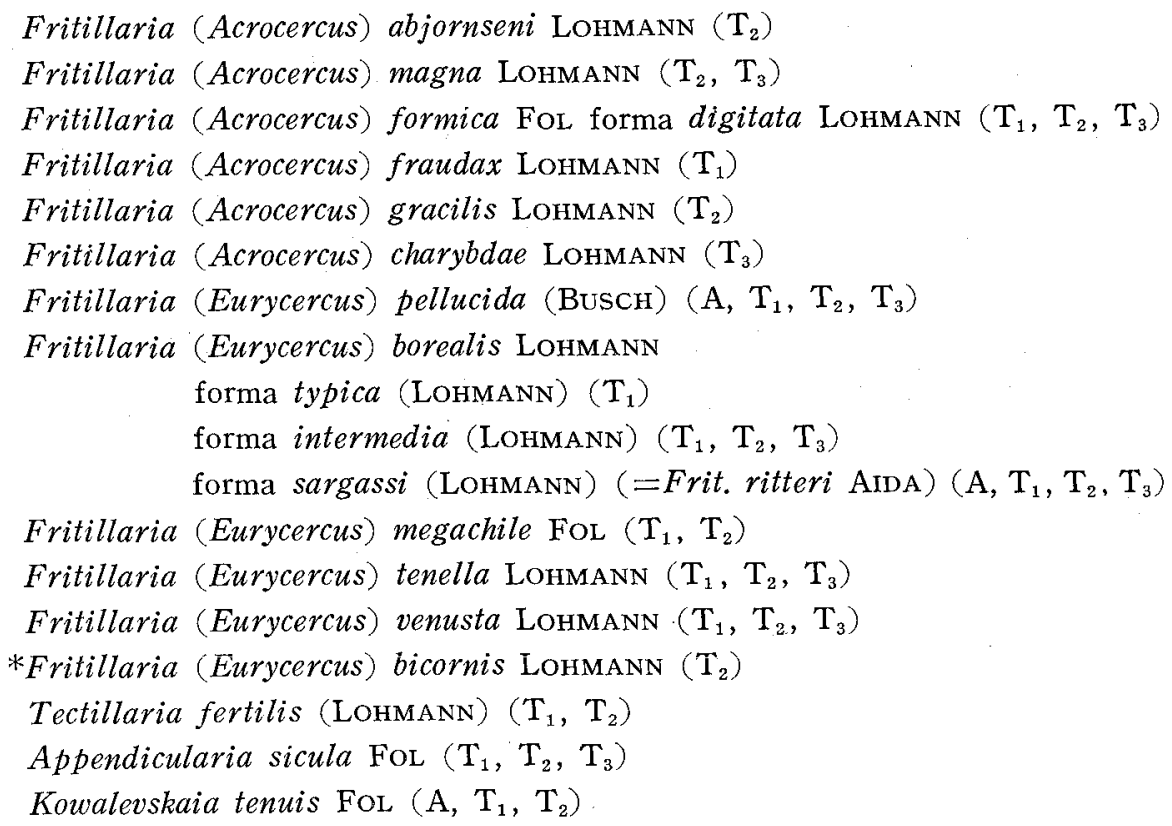

Among these species, Oik. chamissonis is considered as being identical with Oik. labradoriensis; Oik. cornutogastra seems to be adequately treated as a form of Oik. fusiformis (TOKIOKA 1951); Fritillaria bicornis is undoubtedly a synonym of Frit. venusta as fully discussed in my previous paper (1951). Pelagopleura sp. $\left(\mathrm{T}_{3}\right)$ is probably an imperfectly preserved specimen of Pel.verticalis. Chunopleura microgaster reported in my paper of 1940 seems to be a decrepit individual of Stegosoma magnum, which has discharged all genital products out of the body. I have found, since 1940, several individuals of St. magnum in such state as figured and described in my previous paper of 1940 under the name of Chunopleura microgaster. Thus, the valid species from Japanese waters and the adjacent seas are reduced to 29 species and 3 forms.

Oik. graciloides, Pelag. verticalis, Frit. abjornseni and Frit. gracilis are only listed in the report given by Tokioka (1942), but there is no description nor figure of these species in any paper dealing with appendicularians in the north-western Pacific. So, I wish to give brief descriptions and sketched figures of specimens of these species found in the material under my disposal in the last section of this article, to certificate the occurrence of these animals in the neighbouring waters of Japan.

\section{The Faunistic Consideration on Japanese Appendicularians.}

Horizontal distribution: Japanese appendicularians may be classified conveniently as follows, as mentioned roughly in my previous paper of 1940 . 
1) Oceanic water form

a. Cold-water forms-Oik. labradoriensis in Oyasio. (Tisima Current), Liman Current, cold waters along the coasts of Hokkaidô (Osyoro) and recently from the deep waters of Japan Sea under the warm Tusima Current.

Frit. borealis forma typica found in the northern waters. of the Sea of Japan.

b. Warm-water forms-Most of the species in the list, excepting those included in groups a and 2. Among warm-water forms, Oik. longicauda is the commonest species and is followed by Oik. fusiformis and Oik. rufescens in Oikopleuridae and Frit. haplostoma is the commonest one and next Frit. pellucida being followed by Frit. formica and Frit. borealis f. sargassi and intermedia in Fritillaridae. AIDA (1907) says that Kowalevskaia tenuis is also a common visitor to the Pacific coast of Japan and is found during the summer in the swarm of Noctiluca, although the present species seems to be rather a rare one in my own experience.

2) Inlet-water form

Oik. dioica is found commonly and abundantly in every bay or inlet along the coasts of Japan and the adjacent regions, which holds stagnant water. This species is also found, though sparsely, in the offshore water as a drift-form from the inlet waters. In such cases, the animal seems to grow much larger than in the inlet waters. Oik. longicauda and Frit. haplostoma are frequently found in a considerable number in some bays or inlets, although it is certain that they are drifted into there from the open sea. (As to the latter species see the item of Frit. abjornseni.) The distribution of Appendicularia sicula is not certain. It is, however, a noteworthy fact that App. sicula is met with, in my experience, much of tener in samples from bays or inlet waters in the temperate or tropical regions than in those from the open sea.

Vertical distribution: There are merely a few data about the vertical distribution of this animal group in Japanese waters. According to my previous paper in 1951, appendicularians seem to be scarce both in the superficial layer and in the depths. I found only 3 Oikopleura and 1 Fritillaria in two samples hauled below $150 \mathrm{~m}$. Of these 4 specimens, one is Oik. longicauda and other one is Oik. rufescens, while the rest can not identified clearly, because they are in a wrong state of preservation. FuruHAshi (1952) gives the following data that Oikopleura sp. occupied 1.4-11.1\% of the whole zooplankton hauled between $140 \mathrm{~m}-400 \mathrm{~m}$ at two stations off San'in District.

Occurrence in swarm: AIDA (1907) reports that Oik. rufescens occurred once in the summer of 1897 in an exceptionally great swarm invaded the harbour of Misaki after a strong southern wind, thickly becrowding the surface water all over with castoff "houses". I met with, once on January 31, 1949, to my own experience, a coloured stream, ca. $50 \mathrm{~m}$ long $\times 1-2 \mathrm{~m}$ wide, formed by fully mature individuals of Oik. longicauda, which appeared in Tanabe Bay not so far from the northern shore of our Laboratory. Frit. haplostoma occurs sometimes in a dense swarm in the super: ficial water near the southern shore of the Laboratory on some extremely calm days accompanied with a breeze from the south. This phenomenon seems to be produced by the same mechanism as what causes the red water of Noctiluca along our coasts. Namely many individuals of Frit. haplostoma floating in the superficial water as Noctiluca are blowed together by a breeze to an enormously dense swarm at some places under special topographic conditions. 


\section{Some Taxonomic Notes.}

\section{Oikopleura graciloides LoHMANN \& BüCKMANN, 1924.}

(Fig. 1)

Bückmann, AD. (1923 a): Beitrag zur Kenntnis der Appendicularien. Auszug aus der Doktorarbeit, $10 \mathrm{~s}, 1 \mathrm{Abb}$.

Bückmann, AD. (1924): Bemerkungen über Appendicularien aus der Ausbeute der Deutschen Sudpolar-Expedition. Zool. Anz., Bd. 59.

Oikopleura californica-Essenberg, CH. (1926): Copelata from the San Diego Region. Univ. California, Publ. Zool., Vol. 28, No. 22.

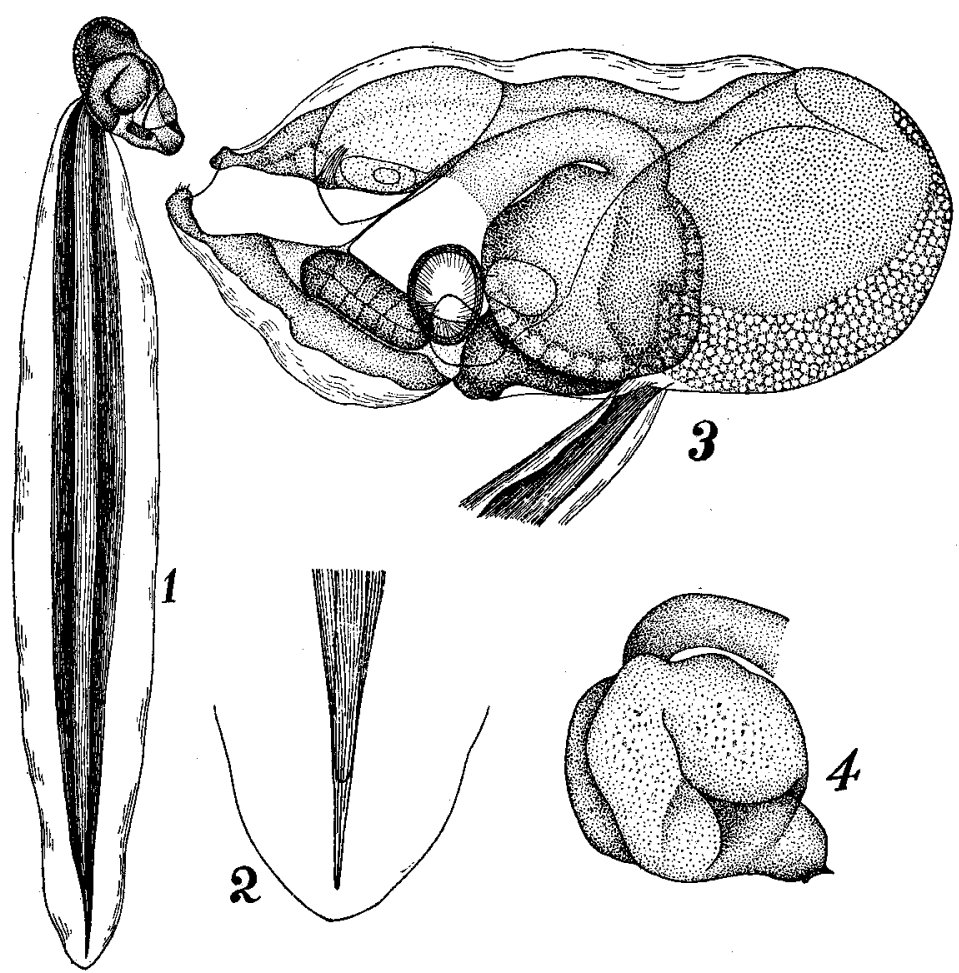

Fig. 1. Oikopleura graciloides LOHMANN \& BÜCKMANN.

$1 \cdots$ Entire animal ; $2 \cdots$ Tip of tail, $\times$ ca. $45 ; 3 \cdots$ Trunk, left side, $\times 200$;

4 ... Alimentary canal, right side, $\times 200$.

Trunk: Small species. Trunk elongate ovoid, $310-430 \mu$ in length in mature state. Oral gland absent. Endostyle is short and situated much nearer the anus than the mouth. The left lobe of the stomach nearly round in outline, the oesophagus opens near the dorsal end of the stomach. Intestine short, anus situated nearly at the level of the anterior end of the mass of the alimentary canal. Gonad extends dorsoposteriorly. The antero-ventral parts of the gonad cover on each side a $1 / 3$ or $1 / 2$ 
of the mass of the alimentary organs. Ovary median.

Tail: Very long, ca. 5.5 times the length of the trunk. Tail musculature rather slender, ca. 3 times the breadth of the chorda which falls in a considerable distance from the posterior end of the musculature. Subchordal cell absent.

Locality: North and South Atlantic, the Mediterranean Sea near Messina (LoHMANN 1896, 0-150 m); Bismark Archipelago (FrIEdRICH DAHL 1896-97). Sparsely in the neighbouring waters of the Palao Islands (TokIokA 1942).

\section{Pelagopleura verticalis (LOHMANN), 1914}

(Fig. 2)

Althoffia verticalis-Lommann, H. (1914): Die Appendicularien der Valdivia-Expedition. Verhandlungen d. Deutschen Zoologischen Gesellschaft, pp. 157-192.

Pelagopleura verticalis - Lohmann und Bückmann (1926): Die Appendicularien der Deutschen Südpolar-Expedition. Deutsch. Südpolar-Exped., Bd. 18, Zool. Bd. 10.

Trunk: Rather elongate, ca. $2.2 \mathrm{~mm}$ in length and ca. $1 \mathrm{~mm}$ in width in the most perfectly preserved specimen. Endostyle is short and situated much nearer the oral aperture than the anus. Oral gland absent. Spiracles not longer than the endostyle. The alimentary canal is situated on the sagittal plane of the trunk. Stomach roughly roundish in outline, oesophagus enters the stomach at the mid-dorsal point and the intestine is issued from the antero-dorsal corner of the stomach. Ovary and testis are both paired. Testis covers the lateral side of the posterior half of the trunk, the anterior end of this organ reaches the posterior margin of the oikoplast epithelium, far beyond the stomach. Ovaries are much smaller than testes and each is situated between the testis and the alimentary canal. It is roughly a triangular plate located vertically. The posterior half extends beyond the posterior margin of the stomach and tapers to a blunt apex, while the anterior half covers the postero-ventral part of thé stomach and bends outward along the anterior margin. A complex lobation occurs on the ovary in maturity and makes the shape of the latter much more complex than the general appearance described above.

Tail: Tail reaches nearly 3 times the trunk length. Tail musculature narrow, ca. two times the width of the chorda which falls far apart from the posterior end of the musculature. There are ca. 10 groups of tail-cells, each of which is rather vacuolate.

Locality: Former records are from Bengal Bay (Tiefsee-Expedition), Guinea Current (Südpolar-Expedition) and Bismark-Archipelago (FrIEDRICH DAHL 1896-97). A few specimens were found in plankton samples hauled in the neighbouring waters of the Palao Islands (ToKIOKA, 1942). 


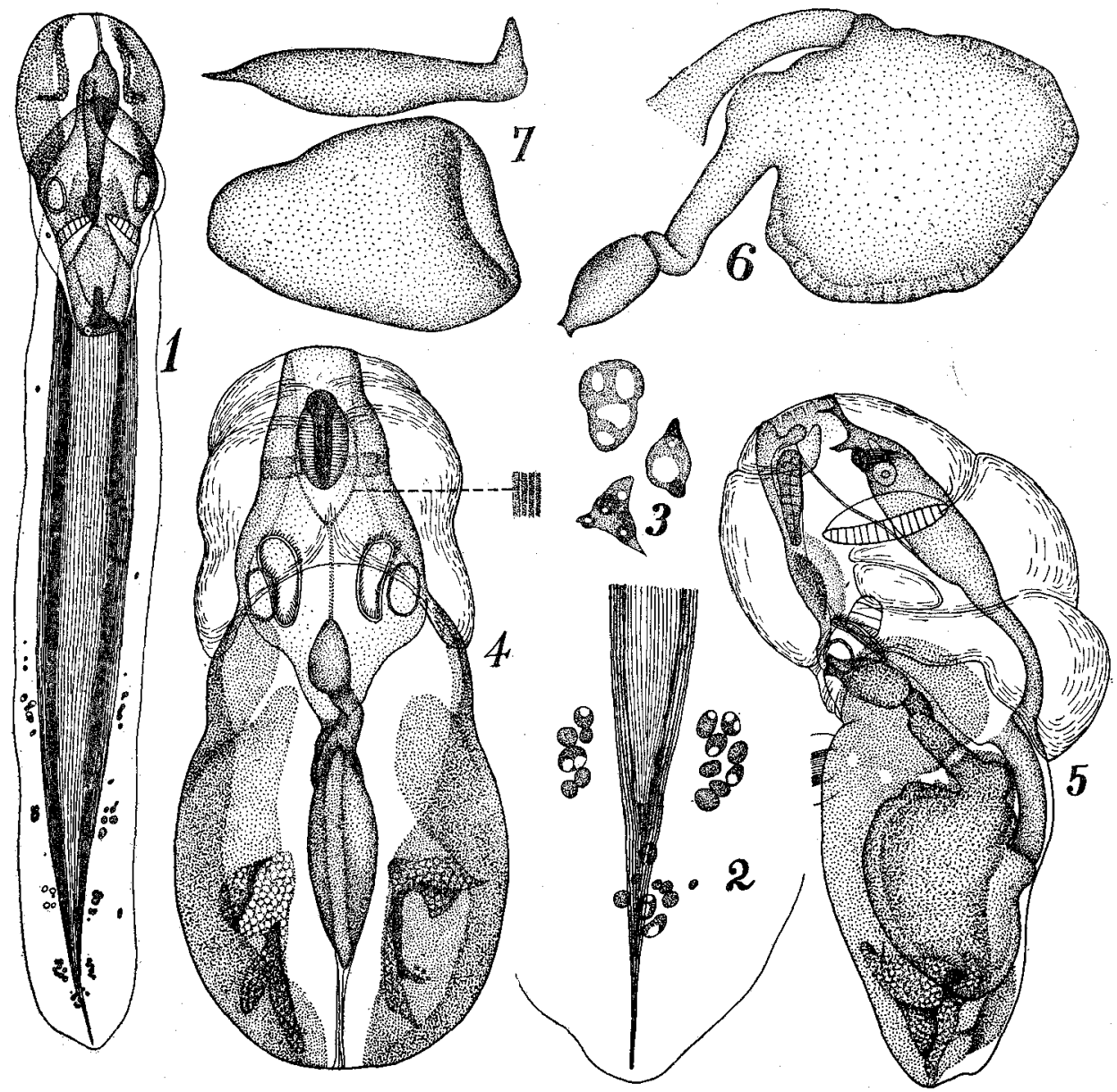

Fig. 2. Pelagopleura verticalis (LOHMANN):

$1 \cdots$ Entire animal ; $2 \cdots$ Posterior end of tail ; $3 \cdots$ A part of a group of tail-cells, $\times 200 ; 4 \cdots$ Trunk, ventral side, $\times 40 ; 5 \cdots$ Trunk, left side, $\times 40 ; 6 \cdots$ Alimentary canal, left side, $\times 55 ; 7 \cdots$ Ovary. above...from ventral side. below $\cdots$ from outside.

\section{Fritillaria abjornseni LoHMANN, 1909}

(Figs. 3 and 4 )

Lohmann, H. (1909): Die Fauna Südwest-Australiens. Bd. II, Lief. 10. Copelata und Thaliacea. pp. 143-149.

Lohmann, H. und Bückmann, Ad. (1926): Die Appendicularien der Deutschen SüdpolarExpedition. Deutsch. Südpolar-Exped., Bd, 18, Zool. Bd. 10.

Fritillaria lohmann-Essenberg, CH. (1926): Copelata from the San Diego Region. Univ. California, Publ. Zool., Vol. 28, No. 22.

Trunk: Small species. Trunk $440-740 \mu$ in length, $620 \mu$ on average. The fundamental structure of the alimentary and genital organs is quite the same as that of 
Frit. haplostoma. The noticeable characteristics of the present species may be found only in the large and round spiracles, large ciliated groove and oikoplast epithelium extending so far back that the distance between the anterior end of the stomach and the posterior margin of the oikoplast epithelium is much smaller than the length of the epithelium itself. Ovary+testis $=$ ca. $1 / 3$ of the trunk length. A gland cell is situated at the postero-lateral corner of each spiracle.

Tail: About $1200 \mu$ in length. The structure is nearly the same as in Frit. haplostoma, although the chorda extends beyond the posterior end of the musculature only slightly and tail-cells are not found on the fin excepting a pair of small ones

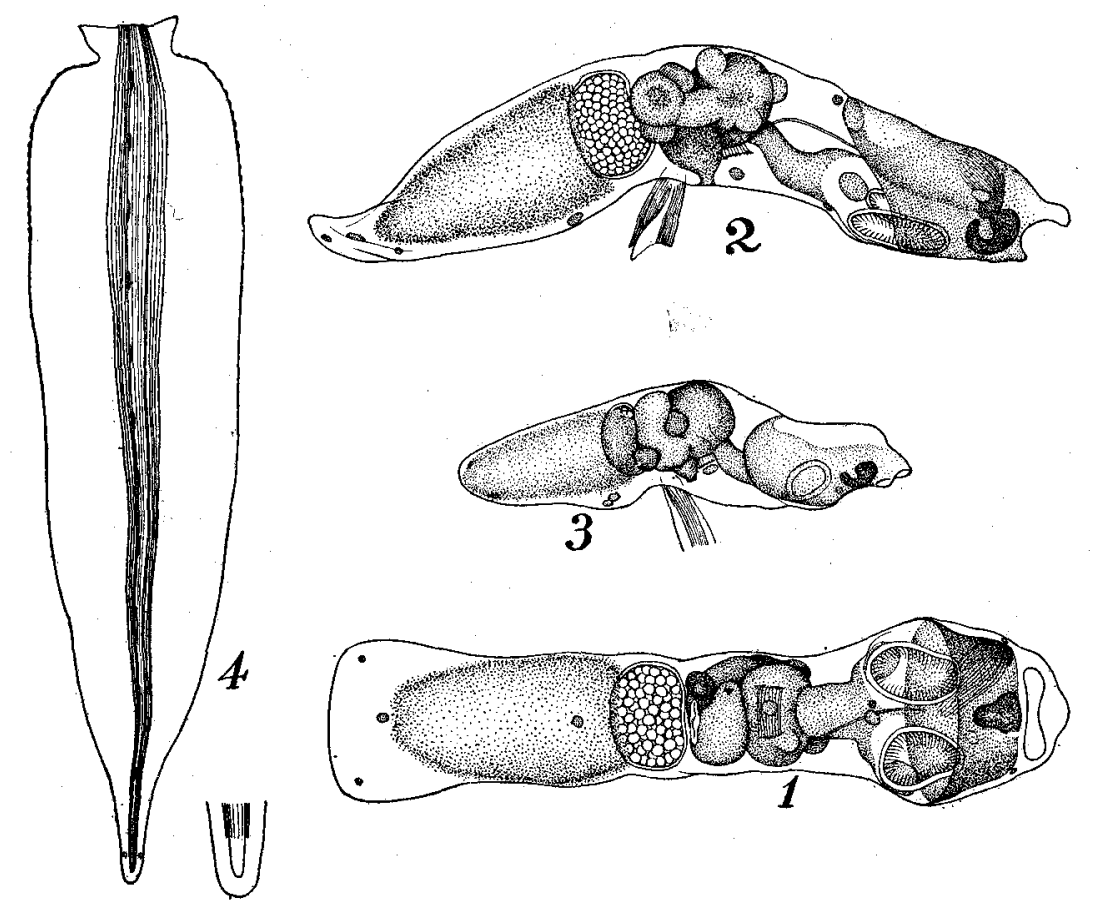

Fig. 3. Fritillaria abjornseni LoHMAnN.

$1 \cdots$ Trunk, ventral side, $\times 110 ; 2 \cdots$ Trunk, right side, $\times 110 ; 3 \cdots$ Trunk of the smallest individual, right side, $\times 110 ; 4 \cdots$ Tail. $\times 70$

near the posterior end. The musculature is narrow, ca. 3 times the width of the chorda at the broadest portion.

Locality: A few specimens of the present species are formerly collected at the estuary of Swan River in the South West Australia and in the Antarctic with the water-temperature $1.8^{\circ} \mathrm{C}$ during the "Südpolar-Expedition". EsSEnBERG (1926) records 2 specimens from the harbour of San Diego. From these localities, this species has been considered to be euryhaline and eurythermal. I found a few specimens in plankton samples hauled in the lagoon of the Palao Islands and in the neighbouring waters. 

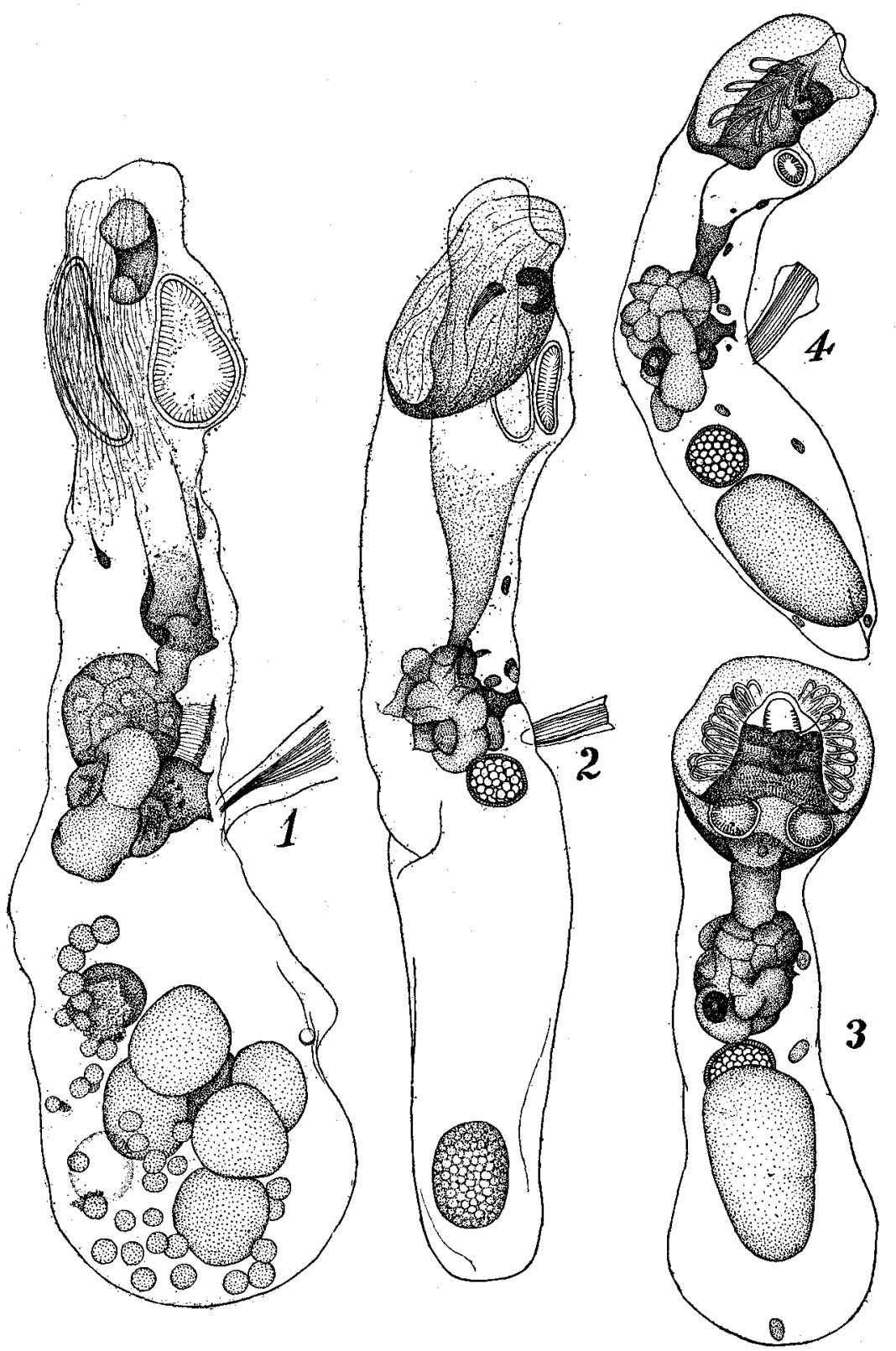

Fig. 4. Fritillaria haplostoma Fol.

$1 \cdots$ Trunk of a large individual, right side; $2 \cdots$ Trunk of another large individual, right side; $3 \cdots$ Trunk of a small individual, ventral side; $4 \cdots$ The same, right side. all $\times 110$. 
Remarks: The Palao specimens are much larger than the original one which is only $250 \mu$ in the trunk length (San Diego specimens are $370 \mu$ ). There is found, however, no difference in structures between the original Australian specimen and the Palao specimens which are shown in Fig. 3. It is a well known fact that Frit. haplostoma varies much in size as I have already mentioned in my previous paper (1951). I give in Fig. 4 figures of three individuals of Frit. haplostoma as the material about this problem. Figs. 1-2 in that figure show larger individuals from the oceanic waters and 3-4 in the figure indicate a small individual from the lagoon waters of the Palao Islands. The larger ones reach $1.4 \mathrm{~mm}$ in length of the trunk and bear large elongate spiracles. Smaller specimens are $\pm 730 \mu$ in length of the trunk and have small round spiracles. These smaller individuals seem to occur oftener in the inlet waters than in the oceanic waters and resemble closely Frit. abjornseni mentioned above. The differences between these smaller Frit. haplostoma and Frit. abjornseni are as follows: 1)-Spiracles and ciliated groove are larger in Frit. abjornseni, 2)-The distance between the anterior end of the stomach and the posterior margin of the oikoplast epithelium is larger in Frit. haplostoma.

It is, however, not impossible that the differences, mentioned above, do not deserve to be considered as those of specific importance. If this supposition is allowed, Frit. abjornseni must be treated as an enormously small form of Frit. haplostoma, which is euryhaline and eurythermal and lives mainly in the coastal or inlet waters.

\section{Fritillaria gracilis LOHMANN, $\mathbf{1 8 9 6}$}

(Figs. 5 and 6)

Lohmann, H. (1897): Die Appendicularien der Plankton-Expedition, Ergebn. Plankton-Exped., Bd. II, Ec.

Trunk: Trunk is oval in outline, slightly compressed dorso-ventrally. It is ca. $1 \mathrm{~mm}$ in length and ca. $720 \mu$ in breadth in fully mature state. Spiracles are comparatively small and round $\sim$ slightly elongate in shape. Intestine is provided with two conspicuous glandular appendages, besides a few irregular glandular prominences. Stomach is usually quite devoid of glandular appendage, although some individuals, for instance a $660 \mu$ long individual (Fig. 6-1), have a few gland cells attached to the stomach. These glandular appendages of the stomach are, however, not so large as the stomach. Testis is a U-shaped ribbon and occupies the posterior portion of the trunk. Ovaries occupy the anterior ends of the testis. Fig. 5 shows an individual, in which mature ova are scattered in the body cavity from ovaries. Fig. 6-1 indicates an immature individual, in which the testis is interrupted medially. Such an arrangement of genital organs is considered to be common to immature individuals of Frit. urticans and Frit. charybdae. The existence of a glandular appendage on 


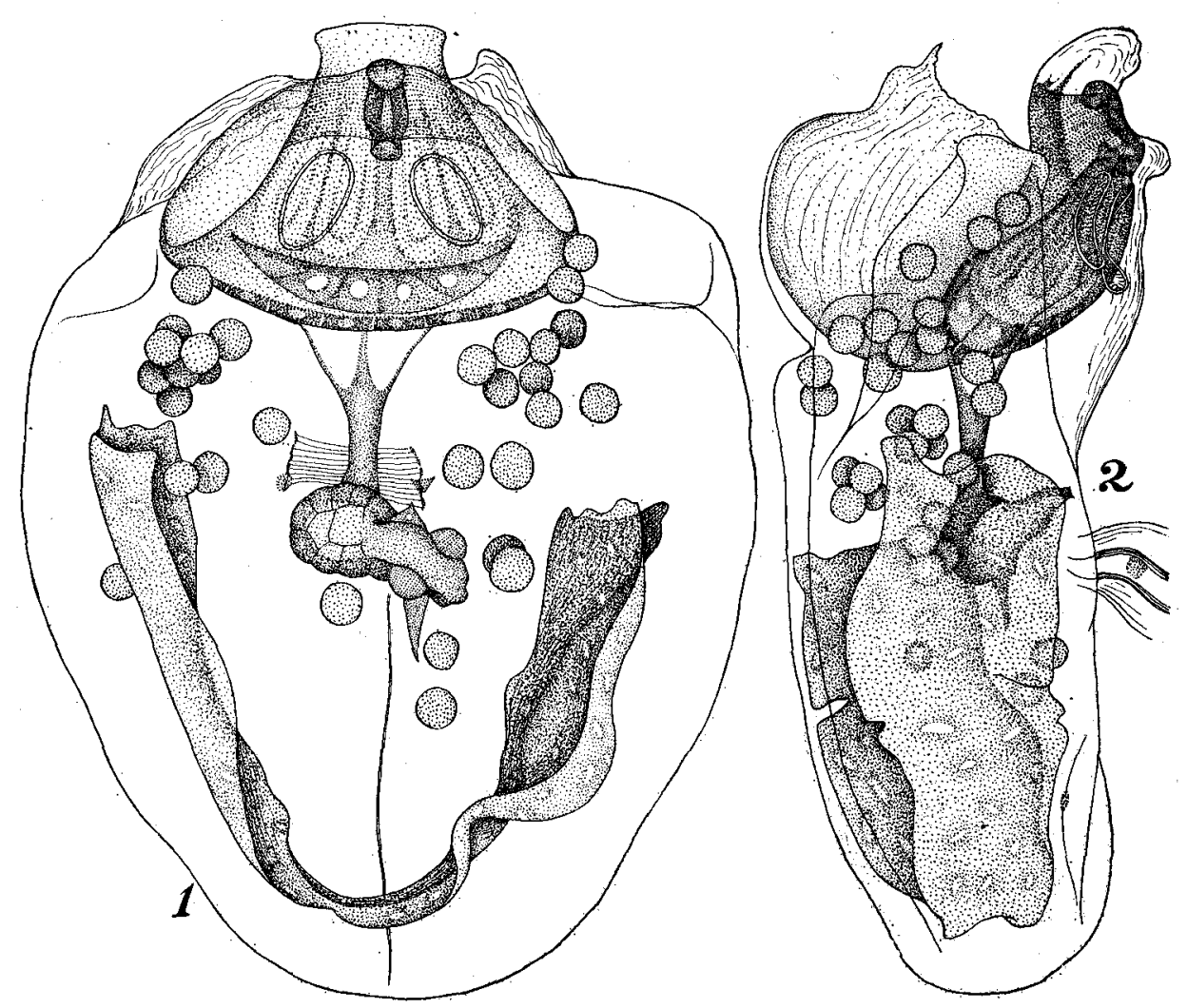

Fig. 5. Fritillaria gracilis LOHMANN.

$1 \cdots$ Trunk, dorsal side, $\times 110 ; 2 \cdots$ Trunk, right side. $\times 110$.

the stomach makes us very reasonably to consider the specimen as a young individual of Frit. charybdae. The glandular appendage is, however, much smaller than in Frit. charybdae. There are two distinct glandular appendages on the intestine. Spiracles small and round. The tail musculature scarcely exceeds the chorda in the width and reaches posteriorly to the posterior end of the chorda. On account of these features I prefer to treat the specimen as a young of Frit. gracilis, which has exceptionally a medially interrupted testis.

Tail: Ca. $1,500 \mu$ in moderately sized individuals. As to the structure of the tail, see the preceding several lines. There are many tail-cells arranged lineally along both lateral margins of the fin.

Locality: Formerly known from the warm waters of the Atlantic and Bismark Archipelago. I got a considerable number of specimens from the stations near the Palao Islands in the North Equatorial Current. 


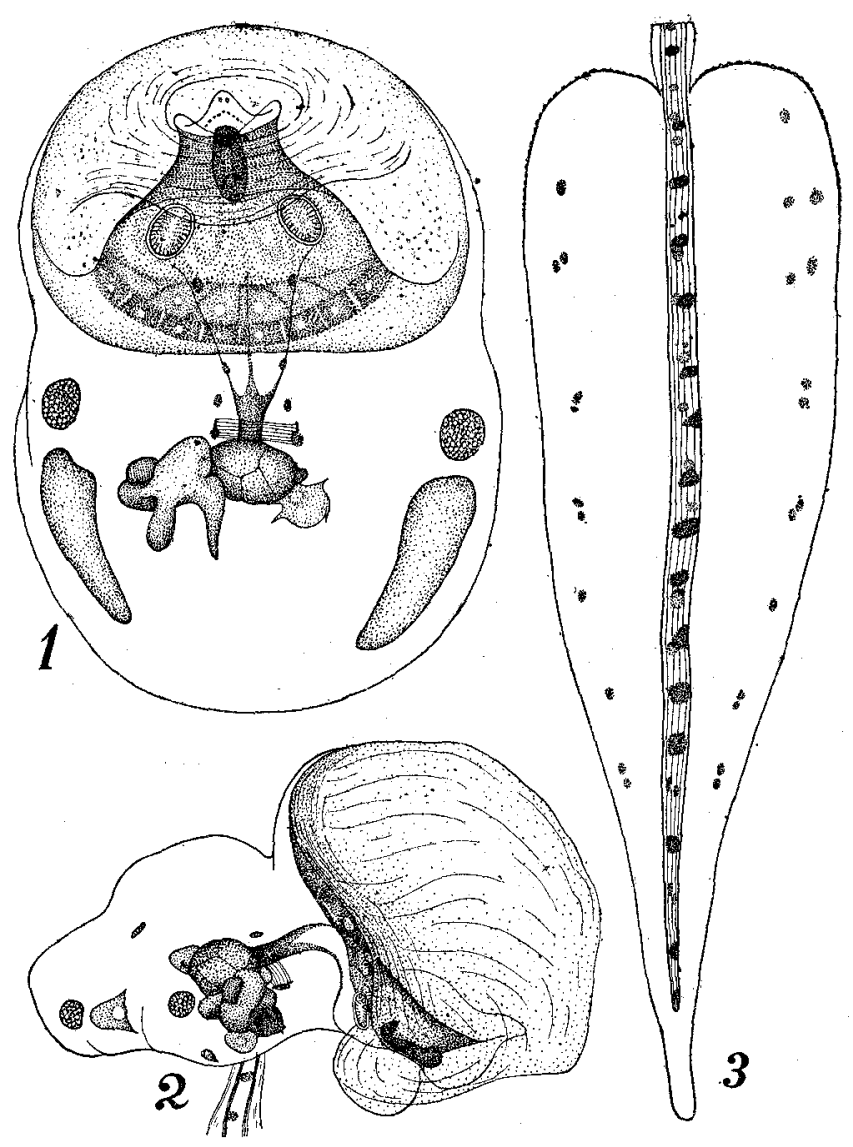

Fig. 6. Fritillaria gracilis LoHMANN.

$1 \cdots$ A $660 \mu$ long trunk, ventral side, $\times 110 ; 2 \cdots$ A small $530 \mu$ long trunk, right side, $\times 110 ; 3 \cdots$ Tail, $\times 70$.

\section{LITERATURE CITED}

A...AidA, T. (1907): Appendicularia of Japanese waters. Jour. Coll. Sci., Imp. Univ. Tokyo, Vol. XXIII, Art. 5.

$T_{1}$..TokrokA, T. (1940): Some additional notes on the Japanese appendicularian fauna. Rec. Oceanogr. Works in Japan, Vol. XI, No. 1.

$\mathrm{T}_{2} \cdots$ (1942): Systematic studies of the plankton organisms occurring in Iwayama Bay, Palao. VII. A preliminary report on the appendicularian fauna of the Bay and the adjacent waters. Palao Trop. Biol. Stat. Studies, Vol. II, No. 3.

$\mathrm{T}_{3} \ldots$ (1951): Pelagic tunicates and chaetognaths collected during the cruises to the New Yamato Bank in the Sea of Japan. Publ. Seto Mar. Biol. Lab., Vol. II, No. 1.

FuruHashi, K. (1952): Notes on some animal planktons collected from the Sea of Japan off San'in-district. Publ. Seto Mar. Biol. Lab., Vol. II, No. 2. 